\title{
Analysis of Fructose 1,6-Diphosphate in Fermentation Broth Using Ion Chromatography
}

\author{
Jian ming Wang ${ }^{1}$, Ying $\mathrm{Xun}^{2}$, Ping $\mathrm{Hu}^{3}$, Jin xiu Zhang ${ }^{2 *}$ and Li-an Wang ${ }^{2 *}$ \\ ${ }^{1}$ Hebei Normal University for Nationalities, Chengde, PRC \\ ${ }^{2}$ The Life Science College, Hebei Normal University, Shijiazhuang, PRC \\ ${ }^{3}$ The Center for Disease Prevention and Control of Shijiazhuang, Shijiazhuang, PRC
}

\begin{abstract}
In this study, a new method for rapid and accurate detection of fructose 1,6-diphosphate (FDP) present in fermentation broth was established using ion chromatography. With an AS11-HC anion column, suppressed conductivity detection, and $50 \mathrm{~m} \mathrm{~mol} / \mathrm{L} \mathrm{KOH}$ elution, qualitative and quantitative analyses of FDP in the fermentation broth can be completed in $5 \mathrm{~min}$. The minimum detection limit of the method for FDP was $0.032 \mu \mathrm{mol} / \mathrm{L}(\mathrm{S} / \mathrm{N}=3)$. Within the concentrations ranging from 3.3 to $211.5 \mu \mathrm{mol} / \mathrm{L}$ a significant linear relationship ( $r=0.9999, p<0.0001)$, good recovery $(99.0 \% \sim 100.3 \%)$, and measurement precision $(\leq 0.04 \%, n=5)$ were obtained. The method can qualitatively analyze $\mathrm{PO}_{4}^{3-}$, fructose-6phosphate, and glucose 6-phosphate in the fermentation broth simultaneously. The results obtained by this method had no significant difference from those obtained using the enzymatic analysis method.
\end{abstract}

Keywords: Fructose 1,6-diphosphate; Ion chromatography; The detection limit; Recovery; Precision

\section{Introduction}

Fructose 1,6-diphophate (FDP) is an important intermediate of glycolysis. It can regulate activities of a variety of glycolytic enzymes [1]. Harden and Young were the first to isolate the compound and clarify its physical and chemical properties in 1908 [2]. Subsequently, great efforts were made to study FDP physiological functions. It is known that FDP can enhance cell metabolism and cardiac myocyte nutrients, build up the resistance to convulsions, improve anoxic organ performance [3-9]. Now it is primarily used as a rescue drug for shock patients, in addition to, or used for angina pectoris, heart failure, myocardial infarction secondary treatment, in the cardiovascular acute and chronic disease treatment and prevention with an important role.

For FDP fermentation production, a lot of studies have been performed on fermentation process, yeast cell cultures, FDP separation and purification, correlation between yeast cell permeability and FDP yield [10-14]. The method of Leisola and Linko using the enzymes of beer fermentation yeast cells to bio-convert sugar and phosphate into FDP for the industrial FDP production is widely used now [12]. In the 1980s, the industrial production of FDP was first accomplished by Foscama, an Italian company and the FDP powder for injection was produced. In 1992, the state-level appraisal of a pilot production of FDP trisodium salt was implemented in China and the production was industrialization in the late 1990s.

With regard to the analysis of FDP, several studies have been performed. In 1954, Roe and Papadopoulos completed the determination of FDP and fructose-6-phosphate with color-reaction of resorcinol and furan ring from FDP or fructose-6-phosphate [15]. However, this method was not applicable to the qualitative analysis of FDP and the results were easily influenced by many factors of a complex course. Subsequently, the analysis of FDP was performed employing under-mentioned enzymatic reaction. The dihydroxyacetone phosphate, a decomposition product of FDP, can oxide nicotinamide adenine 2 nucleotide (NADH) into nicotinamide adenine dinucleotide (NAD) under the action of glycerol-3- phosphate dehydrogenase. Changes in the NADH absorbance value at $340 \mathrm{~nm}$ were correlated with the changes in FDP contents [16]. This method is very specific and accurate, but it has multiple steps and is time consuming. Additionally it requires controlled temperatures, reaction mixture $\mathrm{pH}$, and other experimental conditions. It cannot be used for a rapid and on-line quantification of FDP levels in industry.

Over the years, ion chromatography, as a rapid and simple method for the analysis of hydronium, has been widely used in the analyses of trifluoroacetic acid, oxalate, sodium cyclamate and other organic compounds [17-19]. In this study, a simple, rapid ion chromatographic method was established for FDP qualitative and quantitative analyses.

\section{Materials and Methods}

\section{Experimental instruments}

DX-600 Ion Chromatography (Dionex Corporation, USA) including EG40 automatic eluent generation system, ED50 Conductivity Detector, AS50 auto-sampler, ATC-I anion trap column and an ASRSII $(2 \mathrm{~mm})$ anion self regenerating suppressor operating in the autosuppression recycle mode, using a Dionex IonPac AS11-HC analytical column $(2 \times 250 \mathrm{~mm})$ and AG11-HC guard column $(2 \times 50 \mathrm{~mm})$. The detector sampling rate was $0.2 \mathrm{~s}$. Dionex PeakNet6.0 software was used for hardware control, detector signal acquisition and chromatographic peak integration. $0.22 \mu \mathrm{m}$ filter membrane (Millipore Corporation, USA); ultra-pure water system (Millipore Corporation, USA).

\section{Experimental methods}

Preparation of an FDP fermentation broth: The fermentation

*Corresponding author: Jinxiu Zhang, The Life Science College, Hebei Normal University, Shijiazhuang 050024, PRC, Tel: +86-0311-80787572; E-mail: xiudou882003@163.com

Li-an Wang, The Life Science College, Hebei Normal University, Shijiazhuang 050024, PRC, Tel: +86-0311-80787571; E-mail: wlian1965@126.com

Received: September 01, 2015; Accepted: September 23, 2015; Published September 26, 2015

Citation: Wang JM, Xun Y, Hu P, Zhang JX, Wang L (2015) Analysis of Fructose 1,6-Diphosphate in Fermentation Broth Using Ion Chromatography. Biochem Anal Biochem 4: 209. doi:10.4172/2161-1009.1000209

Copyright: $\odot 2015$ Wang JM, et al. This is an open-access article distributed under the terms of the Creative Commons Attribution License, which permits unrestricted use, distribution, and reproduction in any medium, provided the original author and source are credited. 
mixture $(200 \mathrm{~mL})$ contained $19.64 \mathrm{~g}$ glucose, $6.24 \mathrm{~g} \mathrm{NaH}_{2} \mathrm{PO}_{4}, 14.32 \mathrm{~g}$ $\mathrm{Na}_{2} \mathrm{HPO}_{4}, 0.552 \mathrm{~g} \mathrm{MgCl}_{2}, 20 \mathrm{~g}$ dry yeast powder, and distilled water. The mixture was well mixed and shaken at $37^{\circ} \mathrm{C}$ and $160 \mathrm{rpm}$ for $2.5 \mathrm{~h}$. Then the fermentation broth was incubated for $10 \mathrm{~min}$ in boiling water and then centrifuged at 10,000 $\mathrm{g}$ for $5 \mathrm{~min}$. The precipitation was discarded and the supernatant was collected and kept at $4^{\circ} \mathrm{C}$ for future analysis.

Sample processing: Ultrapure water $(18.2 \mathrm{M} \Omega)$ was used to prepare the following solutions:

FDP stock solution: $2.5 \mathrm{mg} \mathrm{FDPNa} \cdot 8 \mathrm{H}_{2} \mathrm{O}$ (Sigma) in $25 \mathrm{~mL} \mathrm{H}_{2} \mathrm{O}$.

Solution I: $2.5 \mathrm{mg} \mathrm{FDPNa} \cdot 8 \mathrm{H}_{2} \mathrm{O}, 3.0 \mathrm{mg}$ D-fructose-6-phosphate sodium (Sigma) in $25 \mathrm{~mL} \mathrm{H}_{2} \mathrm{O}$.

Solution II: $10.0 \mathrm{mg} \mathrm{FDPNa}_{3} \cdot 8 \mathrm{H}_{2} \mathrm{O}$ and $1.0 \mathrm{mg}$ D-glucose -6 phosphate sodium (Sigma) in $25 \mathrm{~mL} \mathrm{H}_{2} \mathrm{O}$.

Solution III: $8.0 \mathrm{mg} \mathrm{FDPNa}_{3} \cdot 8 \mathrm{H}_{2} \mathrm{O}$ and $3.0 \mathrm{mg} \mathrm{Na} \mathrm{HPO}_{4} \cdot 7 \mathrm{H}_{2} \mathrm{O}$, in $25 \mathrm{~mL} \mathrm{H}_{2} \mathrm{O}$.

Solution IV: $2.5 \mathrm{mg} \mathrm{FDPNa}{ }_{3} \cdot 8 \mathrm{H}_{2} \mathrm{O}$ and $3.0 \mathrm{mg}$ D-fructose in 25 $\mathrm{mL} \mathrm{H}_{2} \mathrm{O}$.

Solution V: $2.5 \mathrm{mg} \mathrm{FDPNa}{ }_{3} \bullet 8 \mathrm{H}_{2} \mathrm{O}$ and $3.0 \mathrm{mg}$ D-glucose in $25 \mathrm{~mL}$ $\mathrm{H}_{2} \mathrm{O}$.

Solution VI: $0.25 \mathrm{mg}$ FDPCa in $100 \mathrm{~mL} \mathrm{H}_{2} \mathrm{O}$.

Solution VII: $1.0 \mathrm{mg}$ FDPCa in $100 \mathrm{~mL} \mathrm{H}_{2} \mathrm{O}$.

Solution VIII: $2.0 \mathrm{mg}$ FDPCa in $100 \mathrm{~mL} \mathrm{H}_{2} \mathrm{O}$.

SolutionIX: $4.0 \mathrm{mg}$ FDPCa in $100 \mathrm{~mL} \mathrm{H}_{2} \mathrm{O}$.

Solution X: $6.0 \mathrm{mg}$ FDPCa in $100 \mathrm{~mL} \mathrm{H}_{2} \mathrm{O}$.

Solution I, II, III, IV, V, VI, VII, VIII and the supernatant of the FDP fermentation $\left(2.2 .1\right.$, kept at $\left.4^{\circ} \mathrm{C}\right)$ were diluted with ultrapure water $(18.2$ $\mathrm{M} \Omega$ ) to the desired concentrations, filtered through $0.22 \mu \mathrm{m}$ membrane, and then directly injected into the DX-600 Ion Chromatography.

Chromatographic conditions: $50 \mathrm{mmol} / \mathrm{L} \mathrm{KOH}$ eluent was used as mobile phase and the flow rate was set at $0.38 \mathrm{~mL} / \mathrm{min}$. The suppressor current was operated at $124 \mathrm{~mA}$ and the conductivity detector cell was set at $30^{\circ} \mathrm{C}$ with $5 \mathrm{~min}$ of running time. The column temperature was set at $30^{\circ} \mathrm{C} .20 \mu \mathrm{L}$ of a sample was injected.

Determination of inorganic phosphorus contents: The assay was conducted according to Biologic et al. [20]. $0.493 \mathrm{mmol} / \mathrm{L}$ of D-fructose-1,6-phosphate trisodium $\left(\mathrm{FDPNa}_{3}\right)$ solution was prepared using $40 \mathrm{mmol} / \mathrm{L}$ or $50 \mathrm{mmol} / \mathrm{L}$ of $\mathrm{KOH}$ solutions, and stirred for 30 $\mathrm{min}$ at $25^{\circ} \mathrm{C}$. The contents of inorganic phosphorus in $\mathrm{FDPNa}_{3}$ solutions added with or without $\mathrm{KOH}$ were measured using this method.

Enzymatic determination of FDP: The assay was conducted according to Yin [16]. In brief, $3 \mathrm{ml}$ of $100 \mathrm{mmol} / \mathrm{L}$ TEA, $0.01 \mathrm{ml}$ of $17 \mu \mathrm{mol} / \mathrm{L} \mathrm{NADH}, 0.1 \mathrm{ml}$ of FDP at defined concentration was mixed, then $\mathrm{OD}_{340}$ was detected and defined as $\mathrm{A}_{1}$. Then, $0.01 \mathrm{ml}$ of $130 \mathrm{u} / \mathrm{L}$ Glyceraldehyde-3-phosphate dehydrogenase (GDH) was added for reaction, $\mathrm{OD}_{340}$ was detected after $15 \mathrm{~min}$ and defined as $\mathrm{A}_{2}$. Then, $0.01 \mathrm{ml}$ of $830 \mathrm{u} / \mathrm{L}$ Triosephosphate isomerase (TIM) was added for reaction, $\mathrm{OD}_{340}$ was detected after $15 \mathrm{~min}$ and defined as $\mathrm{A}_{3}$. At last, $0.01 \mathrm{ml}$ of $150 \mathrm{u} / \mathrm{L}$ aldolase (ALD) was added for reaction, $\mathrm{OD}_{340}$ was detected after $15 \mathrm{~min}$ and defined as $\mathrm{A}_{4}$. All reactions were carried out at $25^{\circ} \mathrm{C}$ unless otherwise noted. The absorption reduction of NADH was $\mathrm{A}_{3}-\mathrm{A}_{4}$. The concentration of the FDP could be calculated by the reduction of $\mathrm{NADH}$, and the total equation was showed below.
$\mathrm{FDP}+2 \mathrm{NADH}+2 \mathrm{H}^{+} \rightleftharpoons 2$ glycerol-3-p $+2 \mathrm{NAD}^{+}$

Data analysis: All data analysis was conducted using the software Statistica 6.0.

\section{Results}

\section{FDP qualitative analysis}

The separation and retention time of FDP, phosphate, D-fructose6-phosphate, D-glucose-6-phosphate on an AS11-HC-type separation column were studied using different eluent $\mathrm{KOH}$ solutions $(5 \mathrm{mmol} / \mathrm{L}$, $10 \mathrm{mmol} / \mathrm{L}, 20 \mathrm{mmol} / \mathrm{L}, 30 \mathrm{mmol} / \mathrm{L}, 40 \mathrm{mmol} / \mathrm{L}, 50 \mathrm{mmol} / \mathrm{L})$. Our results showed that FDP was strongly retained on the column and not eluted out within $1 \mathrm{~h}$ if the eluent concentration $\leq 30 \mathrm{mmol} / \mathrm{L}$. When the eluent concentrations were increased to 40 and $50 \mathrm{mmol} / \mathrm{L}$, FDP and phosphate, D-fructose-6-phosphate, D-glucose-6-phosphate were all separated and eluted down in $10 \mathrm{~min}$ and $5 \mathrm{~min}$, respectively (Figures 1-3).

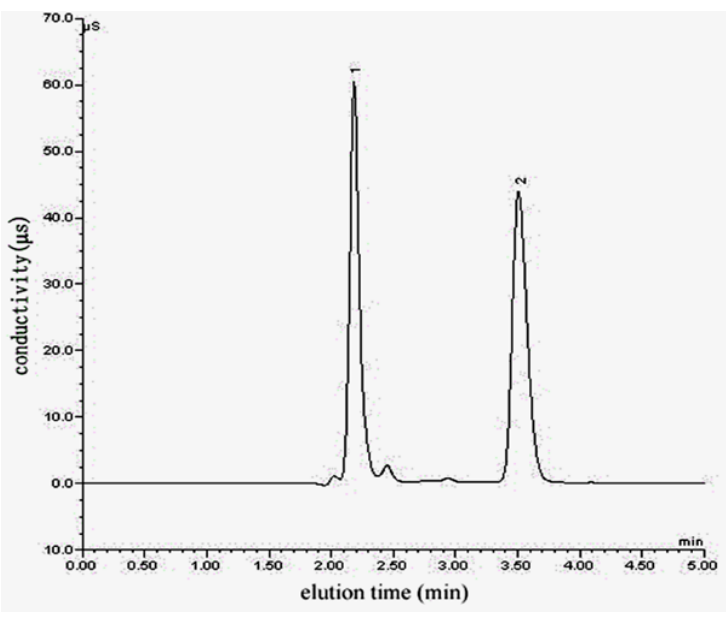

1. Fructose-6-phosphate sodium, $0.375 \mathrm{mmol} / \mathrm{L}$;

2. Fructose-1, 6-diphosphate trisodium, $0.232 \mathrm{mmol} / \mathrm{L}$

Figure 1: Separation of Fructose-1, 6-diphosphate trisodium and Fructose-6phosphate sodium.

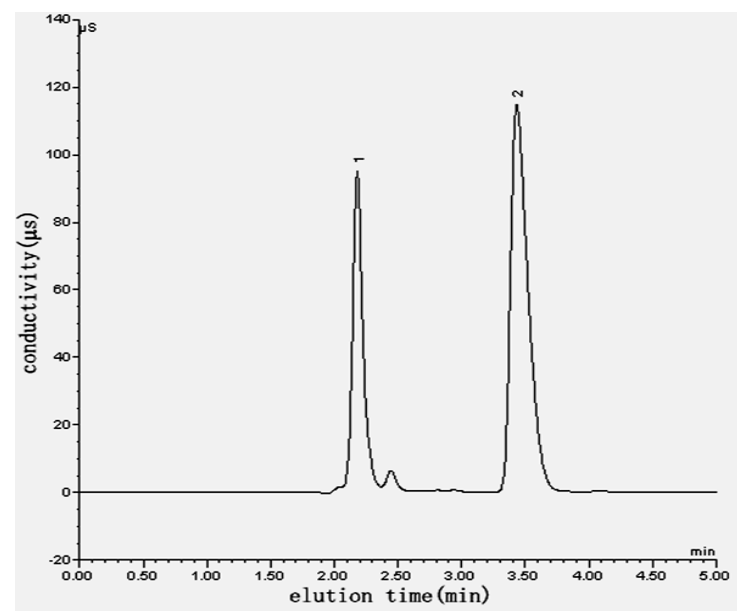

1. Gluctose-6-phosphate sodium, $0.125 \mathrm{mmol} / \mathrm{L}$;

2. Fructose-1, 6-diphosphate trisodium, $0.695 \mathrm{mmol} / \mathrm{L}$.

Figure 2: Separation of Fructose-1, 6-diphosphate trisodium and Gluctose-6phosphate sodium. 


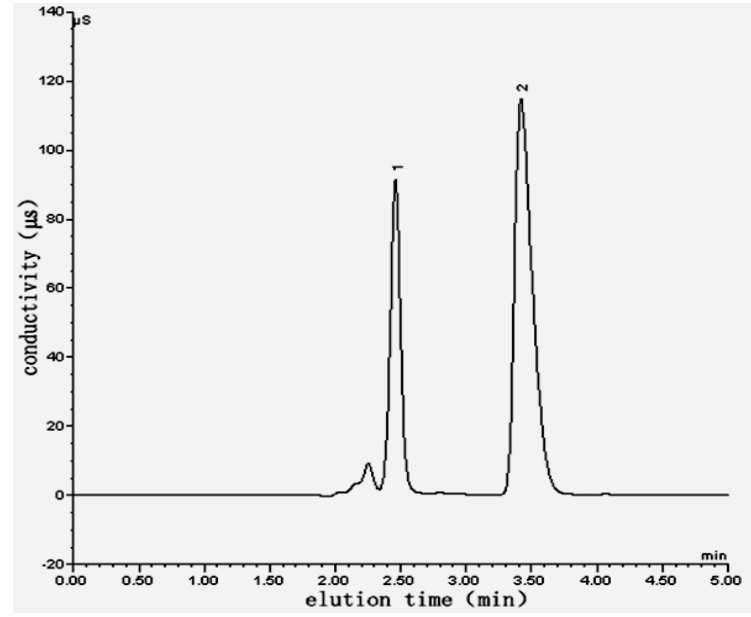

1. Sodium phosphate, $0.425 \mathrm{mmol} / \mathrm{L}$;

2. Fructose-1, 6-diphosphate trisodium, $0.683 \mathrm{mmol} / \mathrm{L}$

Figure 3: Separation of Fructose-1, 6-diphosphate trisodium and Sodium Phosphate.

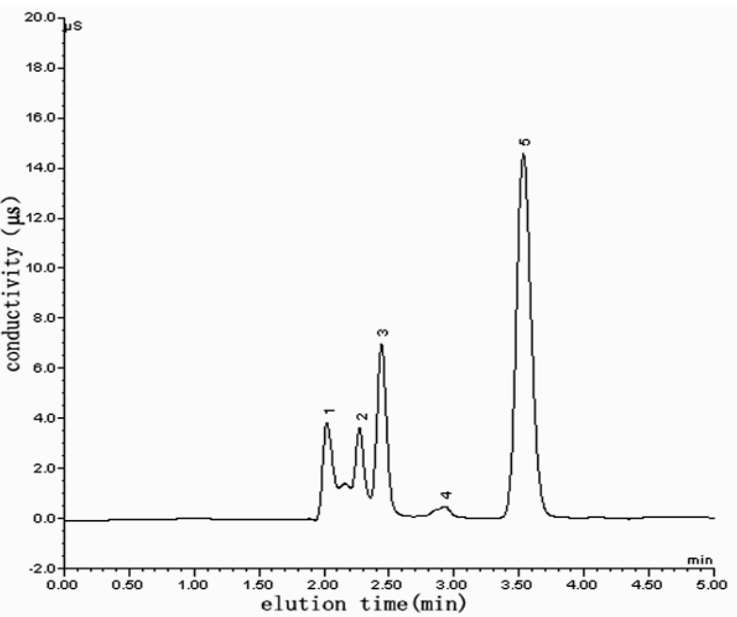

1. $\quad \mathrm{Cl} ; 2 . \mathrm{NO}_{3}^{-} ; 3 . \mathrm{PO}_{4}^{3-;}$ 4. Unknown; 5. FDP

Figure 4: Chromatogram of FDP fermentation with a dilution of 2000 fold $(2.25 \mathrm{~h})$.

The determination data of inorganic phosphorus in $\mathrm{FDPNa}_{3}$ solutions added with or without $\mathrm{KOH}$ using the method described in Section 4.2.4 showed almost no increase in the inorganic phosphorus contents in the $\mathrm{KOH}$-treated $\mathrm{FDPNa}_{3}$ solutions remained unchanged compared to those in the solution not treated, suggesting that dissociation of phosphate group from $\mathrm{FDPNa} 3$ was not significantly enhanced due to the presence of the tested concentrations of $\mathrm{KOH}$ in the eluents. This result was confirmed in the follow-up experiments.

To identify the peaks eluted at $3.53 \mathrm{~min}$ using $50 \mathrm{mmol} / \mathrm{L} \mathrm{KOH}$ eluent, Solution I , II , III, IV and V were injected after filtered as described in Section 4.2.2. The results are presented in Figures 1-3, revealing that there was no peak of $\mathrm{D}$-fructose or $\mathrm{D}$-glucose (Solution IV and V) (data not shown) under the conditions described in Section 4.4. Additionally, the result, no increase in the peak area of $\mathrm{PO}_{4}^{3-}$ in Figures 1-3, again confirmed that dissociation of phosphate group from $\mathrm{FDPNa}_{3}$ did not occur when eluted with $50 \mathrm{mmol} / \mathrm{L} \mathrm{KOH}$. Thus, the peak at 3.53 min was indeed FDP. The resolutions of chromatographic peaks between FDP and D-fructose-6-phosphate, D-glucose-6- phosphate or sodium dihydrogen phosphate were 7.487 (usp), 6.373 (usp) and 4.863 (usp), respectively, all being greater than 1.5, indicating that the target FDP was completely separated from the three above compounds. With the $50 \mathrm{mM} \mathrm{KOH}$ eluent, the samples of the FDP fermentation broth (diluted 2000-fold) were analyzed and FDP was also completely separated from other compounds (Figure 4). These results suggest that identification of FDP in the fermentation broth can be conducted using $50 \mathrm{mmol} / \mathrm{L} \mathrm{KOH}$ solution as the eluent, with which the analysis resulted in better peak parameters and much shorter of running time than with $40 \mathrm{mmol} / \mathrm{L} \mathrm{KOH}$ (data not shown). Therefore, $50 \mathrm{mmol} / \mathrm{L} \mathrm{KOH}$ solution was used in future analyses.

\section{Standard curve and detection limit}

The reproducibility of retention time, chromatographic peak height and chromatographic peak area: esults concerning reproducibility of peak retention time, peak height and peak area obtained from 5 repeated analyses of 2000-fold diluted FDP fermentation samples using the methods described in Section 4.2.3 were presented in Table 1. The relative standard deviation (RSD) of the peak retention times was quite low, suggesting that the retention times of the compounds were highly consistent. This is basis for FDP qualitative analysis. The RSD of peak areas was smaller than that of peak heights, indicating that peak areas had higher reproducibility than peak heights, thus, the values of chromatographic peak areas were chosen for FDP standard curve plotting.

FDP standard curve for quantitative analysis: Standard FDPNa solutions of $0.0033,0.0066,0.0132,0.0264,0.0529,0.1058$, and 0.2115 $\mathrm{mmol} / \mathrm{L}$ were prepared and analyzed as described in Section 4.2.2 and 4.2.3. The FDP concentration was plotted against peak areas to get a stand curve (Table 2). Within the range from 0.0033 to $0.2115 \mathrm{mmol} / \mathrm{L}$, FDP peak areas were positively correlated with the concentrations $(\mathrm{r}=0.9999, \mathrm{p}<0.0001)$ and the resulting regression equation could be used for FDP quantitative analysis.

The limit of detection (LOD) and the lowest limit of quantification (LOQ): In this study, the concentration of FDP sample resulted in the ratio $\mathrm{S}$ (peak height) $/ \mathrm{N}$ (baseline noise) $=3: 1$ is defined as the minimum detection limit and the lowest concentration of FDP plotted in the standard curve is defined as the lowest limit of quantification. Our study revealed that the values of LOD and LOQ were $0.032 \mu \mathrm{mol} / \mathrm{L}$ and $3.3 \mu \mathrm{mol} / \mathrm{L}$, respectively.

\section{Precision}

Analysis precision was obtained from quantification results of

\begin{tabular}{|l|c|c|c|}
\hline Factors studied & Mean & SD (\%) & RSD (\%) \\
\hline Elution $(\mathrm{min})$ & 3.539 & 1.26 & 0.36 \\
\hline Peak height $(\mu \mathrm{s})$ & 12.457 & 4.65 & 0.37 \\
\hline Peak area $\left(\mu \mathrm{s}^{\star} \mathrm{min}\right)$ & 1.650 & 0.36 & 0.22 \\
\hline
\end{tabular}

Table 1: Reproducibility studies of retention time, peak height and peak area $(n=5)$.

\begin{tabular}{|c|c|}
\hline Sample & FDP \\
\hline Linear range $(\mathrm{mmol} / \mathrm{L})$ & $0.0033-0.2115$ \\
\hline Linear regression & \\
\hline Slope & $26.523 \pm 0.0119$ \\
\hline Intercept & $-0.0286 \pm 0.0103$ \\
\hline Regression coefficient & 0.9999 \\
\hline Equation & $y^{\mathrm{a}}=26.523 x^{\mathrm{b}}-0.0286$ \\
\hline
\end{tabular}

Table 2: Results of linearity tests.

${ }^{\text {a }} y$ : peak area; ${ }^{\mathrm{b}} x$ : the concentration of FDP 


\begin{tabular}{|c|c|c|}
\hline FDP concentrations $(\mathbf{m m o l} / \mathbf{L})$ & Mean $^{\text {a }}$ (mmol/L) & RSD $^{\text {b }} \mathbf{( \% )}$ \\
\hline 0.0066 & 0.00658 & 2.50 \\
\hline 0.0264 & 0.02664 & 1.01 \\
\hline 0.0529 & 0.05324 & 0.63 \\
\hline 0.1058 & 0.10606 & 0.39 \\
\hline 0.1587 & 0.15834 & 1.09 \\
\hline
\end{tabular}

aThe data was based on five replicates;

${ }^{\mathrm{b}}$ The data was figured basing on five FDP determination replicates.

Table 3: Results of precision tests $(n=5)$.

\begin{tabular}{|c|c|c|c|}
\hline $\begin{array}{c}\text { FDP fermentation } \\
\text { (mmol/L) }\end{array}$ & $\begin{array}{c}\text { FDP added } \\
\text { (mmol/L) }\end{array}$ & $\begin{array}{c}\text { FDP measured } \\
\text { (mmol/L) }\end{array}$ & $\begin{array}{c}\text { Recovery } \\
\text { ( }\end{array}$ \\
\hline \multirow{3}{*}{0.0066} & 0.0054 & 0.0118 & $96.7 \%$ \\
\hline & 0.0870 & 0.0937 & $100.1 \%$ \\
\hline & 0.1969 & 0.2039 & $100.2 \%$ \\
\hline \multirow{3}{*}{0.0670} & 0.0054 & 0.0723 & $99.0 \% \pm 1.99 \% \pm 2.01 \%^{c}$ \\
\hline & 0.0217 & 0.0886 & 99.1 \\
\hline & 0.0870 & 0.157 & 103.4 \\
\hline \multirow{3}{*}{0.1477} & 0.0027 & 0.1504 & $100.3 \% \pm 2.75 \% \pm 2.74 \%^{c}$ \\
\hline & 0.0217 & 0.1695 & $99.3 \%$ \\
\hline & 0.0435 & 0.1914 & $100.6 \%$ \\
\hline & & & $100.4 \%$ \\
\hline
\end{tabular}

a The data was based on five replicates;

${ }^{\mathrm{b}}$ Recovery was figured basing on the mean of five FDP determination replicates; ${ }^{c}$ Mean $\pm S D \pm R S D$ of recovery.

Table 4: Recovery studies of FDP added in fermentation $(n=5)$.

\begin{tabular}{|c|c|c|c|c|c|c|}
\hline $\begin{array}{c}\text { FDP } \\
\text { fermentation } \\
\text { (mmol/L) }\end{array}$ & Method a & $\begin{array}{l}\text { FDP measured }{ }^{b} \\
(\mathrm{mmol} / \mathrm{L})\end{array}$ & $\mathrm{RSD}^{\mathrm{c}}$ & $\mathbf{F}$ & $\mathbf{P}$ & $\mathbf{t}$ \\
\hline \multirow{2}{*}{0.0033} & 1 & 0.00328 & $4.48 \%$ & \multirow{2}{*}{0.182} & \multirow{2}{*}{0.6811} & \multirow{2}{*}{0.4264} \\
\hline & 2 & 0.00332 & $3.51 \%$ & & & \\
\hline \multirow{2}{*}{0.0132} & 1 & 0.01322 & $1.24 \%$ & \multirow{2}{*}{0.930} & \multirow{2}{*}{0.3641} & \multirow{2}{*}{0.9623} \\
\hline & 2 & 0.01332 & $1.23 \%$ & & & \\
\hline \multirow{2}{*}{0.0264} & 1 & 0.02664 & $1.01 \%$ & \multirow{2}{*}{0.100} & \multirow{2}{*}{0.7103} & \multirow{2}{*}{0.1491} \\
\hline & 2 & 0.02662 & $0.49 \%$ & & & \\
\hline \multirow{2}{*}{0.1058} & 1 & 0.10606 & $0.39 \%$ & \multirow{2}{*}{1.000} & \multirow{2}{*}{0.461} & \multirow{2}{*}{0.775} \\
\hline & 2 & 0.10590 & $0.19 \%$ & & & \\
\hline \multirow{2}{*}{0.2115} & 1 & 0.21146 & $0.53 \%$ & \multirow{2}{*}{0.000} & \multirow{2}{*}{1.000} & \multirow{2}{*}{0.000} \\
\hline & 2 & 0.21146 & $0.09 \%$ & & & \\
\hline
\end{tabular}

a "1": ion chromatographic method, "2": enzymatic method;

${ }^{\mathrm{b}}$ The data was the mean of five replicates;

c The data was figured basing on five FDP determination replicates

Table 5: Comparison between enzymatic method and chromatographic method on FDP determination.

$5 \mathrm{FDPNa}_{3}$ samples with different concentrations using the methods described in Section 4.2.2 and 4.2.3 (Table 3). The values of RSD of 5 replicates from the same sample were all $\leq 2.50 \%$, suggesting high consistency among the measured results. In particular the RSD values of the FDPNa ${ }_{3}$ samples with the concentrations corresponding to the middle of the standard curve were lower than those of the samples with lower or higher FDP concentrations.

This clearly indicated that our method resulted in precise and reproducible quantitative data.

\section{Recovery}

Different amount of FDPNa 3 were added into the fermentation samples with $0.0066,0.0670$, and $0.1477 \mathrm{mmol} / \mathrm{L}$ FDP concentrations.
The quantitative analysis of FDP levels in each sample was performed and recovery was obtained as shown in Table 4 . The recoveries for the three tested fermented samples spiked with different amount $\mathrm{FDPNa}_{3}$ were $100.1 \%, 100.03 \%$ and $99.0 \%$, respectively and all had low RSD, indicating that the results were highly repeatable.

\section{Comparison between ion chromatographic method and en- zymatic determination of FDP}

The ion chromatography method established in this study was compared with the enzymatic quantitative method described in Section 4.2.5 to quantify FDP levels in five different samples. The results were statistically analyzed using STATISTICA 6.0 software (Table 5).

The $\mathrm{F}$ tests showed that $\mathrm{F}$ values for five different samples using two analytic methods were $0.182,0.930,0.100,1.000$, and 0.000 , all smaller than the $\mathrm{F}_{4,4,(0.9)}=6.388$, indicating that the difference in analytic precision was not significant between the two. The $t$ tests indicated that when $\mathrm{P}=0.90, \mathrm{t}$ values were $0.4264,0.9623,0.1491,0.7752$, and 0.0000 , all less than $\mathrm{t}_{010,8}=1.860$, suggesting that there was no significant difference between the two methods.

\section{Discussion}

This study established a new method for FDP qualitative and quantitative analyses. Compared with the enzymatic analytic method, it has the following advantages:

(1) It is rapid. Enzymatic analysis process took about $1 \mathrm{~h} \mathrm{[16]} \mathrm{and}$ this method took only 5 min.

(2) It is highly sensitive. The minimum detection limit of FDP using this method was $0.032 \mu \mathrm{mol} / \mathrm{L}$ and FDP quantification limit was $3.3 \mu \mathrm{mol} / \mathrm{L}$ while the quantitative limit of the enzymatic method was reportedly higher than $9 \mu \mathrm{mol} / \mathrm{L}$ [21]. No reports on FDP minimum detection limits have been found so far. The detection limit using the ion chromatography method could be further reduced if the sample injection volume was increased and a thin analytical column or on-line sample enrichment are employed.

(3) It is known that changes in ambient temperature have a higher degree of impact on the results of enzymatic determination [16]. Therefore the enzymatic assays have to be performed under well controlled temperature conditions. Whereas in this method, an ionchromatography conductivity detector can detect the temperature of the sample right out of the sample cell so that an automatic normalization of measurements are performed to eliminate the impact of temperature variation. Thus, the requirement for a controlled ambient temperature during the course of measurements is not critical.

Using the ion chromatography method established in this study, separation of FDP from $\mathrm{PO}_{4}^{3-}$, fructose-6-phosphate and glucose 6-phosphate in a sample was achieved with the selected elution conditions. However, fructose-6-phosphate and glucose 6-phosphate cannot be separated (data not shown). The separation of the two substances could be realized by optimizing elution conditions, using an effective gradient elution procedure or a highly effective column. Nevertheless, separation of the two compounds does not affect the quantitative analysis of FDP using ion chromatography.

\section{Acknowledgments}

This work was supported by application development Foundation of Hebei Normal University. We acknowledge Shijiazhuang Center for Disease Prevention and Control for the instrumental support. 
Citation: Wang JM, Xun Y, Hu P, Zhang JX, Wang L (2015) Analysis of Fructose 1,6-Diphosphate in Fermentation Broth Using lon Chromatography. Biochem Anal Biochem 4: 209. doi:10.4172/2161-1009.1000209

Page 5 of 5

\section{References}

1. Kirtley ME, McKay M (1977) Fructose-1,6-bisphosphate, a regulator of metabolism. Mol Cell Biochem 18: 141-149.

2. Korman EF (1974) The discovery of fructose-1,6-diphosphate (the HardenYoung ester) in the molecularization of fermentation and of bioenergetics. Mol Cell Biochem 5: 65-68

3. Starnes JW, Seiler KS, Bowles DK, Giardina B, Lazzarino G (1992) Fructose1,6-bisphosphate improves efficiency of work in isolated perfused rat hearts. Am J Physiol 262: H380-384.

4. Riedel BJ, Gal J, Ellis G, Marangos PJ, Fox AW, et al. (2004) Myocardia protection using fructose-1,6-diphosphate during coronary artery bypass graft surgery: a randomized, placebo-controlled clinical trial. Anesth Analg 98: 20-29, table of contents.

5. Lian XY, Khan FA, Stringer JL (2007) Fructose-1,6-bisphosphate has anticonvulsant activity in models of acute seizures in adult rats. J Neurosci 27 : 12007-12011.

6. Markov AK, Brumley MA, Figueroa A, Skelton TN, Lehan PH (1997) Hemodynamic effects of fructose 1,6-diphosphate in patients with normal and impaired left ventricular function. Am Heart J 133 541-549.

7. Zhang JN, Zhang FM, Ma WS, Forrester T (1988) Protective effect of exogenous fructose-1,6-diphosphate in cardiogenic shock. Cardiovasc Res 22: 927-932.

8. Balashov VP, Kostin laV, Sedova DG, Sernov LN, Gatsura VV (1993) The effect of fructose-1,6-diphosphate and phosphoenolpyruvate on the course of early occlusion and reperfusion arrhythmias in rats. Exp Biol Med 115: 629-630.

9. Bernardini N, Danesi R, Bernardini MC, Del Tacca M (1988) Cell Mol Life Sci 441000

10. Compagno C, Tura A, Ranzi BM, Martegani E (1992)Highly efficient bioconversion of glucose into fructose diphosphate with fed-batch-grown Saccharomyces cerevisiae cells. Appl Microbiol Biotechnol 36: 535-537.

11. Compagno C, Tura A, Ranzi BM, Martegani E (1992) Production of fructose diphosphate by bioconversion of molasses withSaccharomyces cerevisiae cells Biotechnol. Lett 14: 495-498.

12. Leisola M, Linko M (1974) Preparation and purification of fructose-1,6 diphosphate. Acta Chem Scand B 28: 555-558.

13. Katayama T, Ishihara H, Okada K, Onda M, Nakajima H (1995) U.S. Pat. Appl. US5 434: 255

14. Melelli F, Tommasi A, Bisso GM (1989) Time-course phosphorylation of glucose by Saccharomyces carlsbergensis following alterations in cell membrane permeability Biotechnol. Lett 11: 669-672.

15. ROE JH, Papadopoulos NM (1954) The determination of fructose-6-phosphate and fructose-1,6-diphosphate. J Biol Chem 210: 703-707.

16. Yin ZM, Ying HJ, Ouyang PK (1993) journal of nanjing institute chemical 13.

17. Hankins DC, Kharasch ED (1997) Determination of the halothane metabolites trifluoroacetic acid and bromide in plasma and urine by ion chromatography $J$ Chromatogr B 692: 413-418.

18. Manoharan M, Schwille PO (1997) Measurement of oxalate in human plasma ultrafiltrate by ion chromatography. J Chromatogr B 700 261-268.

19. Zhu Y, Guo Y, Ye M, James FS (2005) Separation and simultaneous determination of four artificial sweeteners in food and beverages by ion chromatography. J Chromatogr A 1085: 143-146.

20. Baginski ES, Foà PP, Zak B (1967) Microdetermination of inorganic phosphate, phospholipids, and total phosphate in biologic materials. Clin Chem 13: 326-332.

21. Ying HJ, Gu HH, Zhao GL, Ouyang PK, Xu H (2000) J Instrum Anal 19 (2000) 45(Chi.) 